\title{
IDENTIFIKASI SEDERHANA METABOLIT SEKUNDER KULIT BATANG KAWISTA ( Limonia Acidissima L. )
}

\author{
Lia Fikayuniar, S.Farm., M.Si \\ Prodi Farmasi Fakultas Tekhnik dan Ilmu Komputer Universitas Buana \\ Perjuangan Karawang, (Lia.Fikayuniar@ubpkarawang.ac.id) \\ Jl. HS.Ronggo Waluyo, Telukjambe Timur, Karawang, Jawa Barat 41361
}

\begin{abstract}
ABSTRAK
Bukan hanya tumbuhan yang dibudidayakan yang bermanfaat bagi manusia. Ternyata salah satu bagian tumbuhan (seperti kulit batang) yang tersebar disekitar kita sering diabaikan juga menyimpan potensi luar biasa, khususnya sebagai obat (Dalimartha, S., Hembing, W, 1997). Tujuan penelitian adalah untuk mengetahui hasil identifikasi sederhana analisis kualitatif metabolit sekunder kulit batang tanaman kawista (Limonia Acidissima L.) yang dapat dijadikan sebagai senyawa potensial untuk diuji lebih lanjut.

Metode penelitian yang digunakan adalah metode ekstraksi Refluks, pemeriksaan makroskopik, pengujian analisis kualitatif penapisan fitokimia simplisia kulit batang kawista ( Limonia acidissima L. ).

Hasil penelitian berdasarkan karakteristik penetapan kadar air dengan cara destilasi sebesar 1,67 \% v/b. Berdasarkan hasil analisis kualitatif penapisan fitokimia dari kulit batang kawista ( Limonia acidissima L. ) mengandung senyawa golongan flavonoid, saponin, polifenolat, monoterpenoid dan seskuiterpenoid.
\end{abstract}

Kata Kunci : , Kawista, Refluks, Penapisan Fitokimia 


\begin{abstract}
Not only cultivated plants that are beneficial to humans. It turns out that one part of the plant (such as bark) that is scattered around us is often neglected also keeps tremendous potential, especially as medicine (Dalimartha, S., Hembing, W, 1997). The aim of this research is to know the result of simple identification of qualitative analysis of secondary metabolite of bark of kawista plant (Limonia acidissima L.) which can be used as potential compound for further test.

The research method used is the extraction method of reflux, macroscopic examination, qualitative analysis of phytochemical screening of simplicia bark of kawista (Limonia acidissima L.)

The results of the research based on the characteristics of the determination of water content by distillation of $1.67 \% \mathrm{v} / \mathrm{w}$. Based on the results of qualitative analysis of phytochemical screening of bark kawista (Limonia acidissima L.) contains compounds of flavonoids, saponins, polyphenolates, monoterpenoids and sesquiterpenoids.
\end{abstract}

Keyword : Kawista, Reflux, Phytochemical screening

\title{
PENDAHULUAN
}

Pada dasarnya semua tumbuhan yang telah menghijaukan muka bumi ini menyimpan berjuta manfaat. Bukan hanya tumbuhan yang dibudidayakan yang bermanfaat bagi manusia. Ternyata salah satu bagian tumbuhan (seperti kulit batang) yang tersebar disekitar kita sering diabaikan juga menyimpan potensi luar biasa, khususnya sebagai obat (Dalimartha, S., Hembing, W, 1997). Tetapi pada dewasa ini banyak orang yang kembali ke pengobatan alam atau pengobatan tradisional karena disamping mudah didapat juga pada umumnya kurang menimbulkan efek samping yang berbahaya bagi tubuh.

Kawista ( Limonia acidissima L. ) merupakan tanaman berkayu dengan tinggi batang dapat mencapai 12 meter. Tanaman ini banyak dibudidayakan oleh warga maupun tumbuh liar. Buahnya berkulit tebal dan keras. Kulit batang pohon Kawista 
dipercaya juga dapat menjadi campuran jamu untuk mengatasi haid yang berlebihan, gangguan hati, mengatasi mual-mual, bahkan untuk mengobati luka akibat gigitan serangga. Dan menurut jurnal penelitian buah kawista juga digunakan sebagai odorants (Aprianto, 2004), kemudian untuk bagian daunnya digunakan untuk antibakteri (Vijayavargia, 2014). Di Indonesia

Pada penelitian ini dilakukan identifikasi sederhana metabolit sekunder simplisia kulit batang tanaman kawista ( Limonia acidissima L. ), dengan tujuan agar dapat memberikan informasi yang lebih jelas tentang kandungan kimia, dan manfaat dari diketahuinya kandungan kimia yang terkandung pada tanaman ini dapat menunjang untuk pengembangan pengobatan secara tradisional, yang menggunakan bahan dasar kulit batang pohon.

\section{METODE PENELITIAN}

\section{Alat}

Alat-alat yang digunakan dalam penelitian ini adalah pipet tetes, tabung reaksi dan rak, cawan penguap, refluks, penangas air, penjepit kayu, pipa kapiler, oven, mortar dan stemper, penggilingan, alat penetapan kadar air, timbangan analitik, desikator, lemari pendingin, rotavapor, botol semprot.

\section{Bahan}

Bahan Bahan-bahan yang diperlukan untuk penelitian ini meliputi simplisia dan ekstrak kulit batang kawista, metanol, air suling, asam klorida pekat, n-heksan, etil asetat, $\mathrm{NaOH}$, kertas saring, alumunium foil, kloral hidrat, serbuk magnesium, amil alkohol, kuinin sulfat, pereaksi Dragendorff, pereaksi Lieberman Bouchard, vanilin sulfat, kalium hidroksida, toluen, asam sulfat dalam metanol $1 \% \mathrm{v} / \mathrm{v}$, gelatin, amonia, natrium sulfat, kloroform, eter, etanol 95\%.

Proses penelitian meliputi tahap-tahap pengerjaan yaitu penyiapan simplisia, makroskopoik, pemeriksaan kadar air simplisia, penapisan fitokimia,

Tahap penyiapan simplisia meliputi pengumpulan simplisia kulit batang kawista ( Limonia acidissima L. ) segar, pembersihan, perajangan, dan pengeringan. Bahan tanaman diperoleh dari daerah karawang (Jawa Barat). bagian yang diambil sebagai sampel adalah kulit batang kawista ( Limonia acidissima L. ).

Selanjutnya dilakukan pencucian, pengeringan menggunakan oven pada suhu $45^{\circ} \mathrm{C}$, kemudiaan dilakukan penggilingan simplisia dan disimpan dalam wadah yang 
bersih tertutup rapat, sehingga diperoleh serbuk kering simplisia yang siap untuk pengujian selanjutnya.

Pemeriksaan karakteristik simplisia meliputi pemeriksaan makroskopik dan penetapan kadar air cara destilasi, dan analisis kualitatif penapisan fitokimia.

\section{PEMBAHASAN}

Penapisan fitokimia ini dilakukan untuk mengetahui kandungan senyawa metabolit sekunder seperti golongan alkaloid, fenol, flavonoid, saponin, tanin, terpenoid, dan kuinon pada simplisia dapat dilihat pada

Tabel 1. Hasil Pemeriksaan Karakteristik Makroskopis Kulit Batang Kawista ( Limonia acidissima L. )

\begin{tabular}{lc}
\hline & Simplisia \\
\cline { 2 - 2 } Uji Organoleptik & Kulit Batang Kawista \\
\hline Rasa & Tidak berasa \\
Bau & Wangi khas kayu \\
Warna & $\begin{array}{c}\text { Kulit dalam putih pucat kecoklatan, kulit luar } \\
\text { berwarna coklat, atau coklat kehijauan }\end{array}$ \\
Bentuk & Dangkal melengkung, lurus \\
\hline
\end{tabular}

Tabel 2. Penapisan Fitokimia Simplisia Kulit Batang Kawista ( Limonia acidissima L. )

\begin{tabular}{|c|c|c|}
\hline Golongan Senyawa & Pereaksi & Hasil \\
\hline Alkaloida & $\begin{array}{l}\text { Mayer } \\
\text { Dragendorff }\end{array}$ & $\begin{array}{l}\text { (-) tidak ada endapan putih } \\
\text { (-) tidak ada endapan jingga } \\
\text { kuning }\end{array}$ \\
\hline Senyawa Fenol & $\mathrm{FeCl}_{3}$ & (+) hijau biru kehitaman \\
\hline Tanin & Gelatin $1 \%$ & (-) tidak ad endapan putih \\
\hline Flavonoid & $\begin{array}{l}\text { Serbuk Magnesium, } \\
\mathrm{HCl} \text {, amil alkohol }\end{array}$ & $\begin{array}{l}(+) \text { lapisan amil alkohol merah } \\
\text { kekuningan }\end{array}$ \\
\hline
\end{tabular}




$\begin{array}{lll}\begin{array}{ll}\text { Monoterpenoid dan } \\ \text { seskuiterpenoid }\end{array} & \begin{array}{l}\text { Vanilin 10\% dalam } \\ \mathrm{H}_{2} \mathrm{SO}_{4} \text { pekat }\end{array} & (+) \text { berwarna kuning kecoklatan } \\ \text { Steroid dan } & \text { Liebermann- } & (-) \text { tidak terbentuk warna hijau } \\ \text { Triterpenoid } & \text { Buchard } & \text { violet } \\ \text { Senyawa kuinon } & \mathrm{KOH} \mathrm{5 \%} & (-) \text { tidak terbentuk warna kuning } \\ \text { Saponin } & \mathrm{HCl} 2 \mathrm{~N} & (+) \text { busa stabil }>1 \mathrm{~cm}\end{array}$

Pada Tabel 2. dapat dilihat bahwa pada simplisia tersebut di atas positif mengandung metabolit sekunder golongan fenol, flavonoid, saponin, terpenoid, sedangkan golongan alkaloid dan tanin tidak terdeteksi pada simplisia.

Pemeriksaan kadar air dengan cara destilasi yang menunjukkan nilai (1,67\% v/b), hal ini menunjukkan simplisia herba picisan memiliki kualitas yang baik untuk digunakan penelitian kerena memenuhi persyaratan yaitu kadar air nya kurang dari $10 \%$ dan pemeriksaan kadar air yang dilakukan secara destilasi adalah bertujuan untuk menghindari menguapan senyawa bersifat atsiri pada simplisia.

\section{KESIMPULAN}

Hasil pemeriksaan karakteristik terhadap simplisia kulit batang kawista ( Limonia acidissima L. ) dan hasil dari uji kadar air yang memenuhi persyaratan pada buku materia medika Indonesia yaitu kadar air kurang dari $10 \%$, hal ini menunjukkan bahwa simplisia kulit batang kawista memiliki mutu yang baik untuk digunakan penelitian selanjutnya.

Berdasarkan hasil penapisan fitokimia tanaman tersebut mengandung senyawa golongan metabolit sekunder, sehingga hasil ini dapat menjadi dasar penentuan salah satu golongan senyawa yang diisolasi.

\section{Saran}

1. Perlu dilakukan penelitian lebih lanjut tentang penetapan parameter standar mutu ekstrak kulit batang kawista.

2. Perlu dilakukan penelitian lebih lanjut tentang skrining fitokimia ekstrak kulit batang kawista.

3. Perlu dilakukan penelitian lebih lanjut tentang ekstraksi dan isolasi metabolit sekunder ekstrak kulit batang kawista. 


\section{DAFTAR PUSTAKA}

1. Apriyantono, A., Kumara, B., 2004, Jurnal.Teknol. dan Industri Pangan, Vol. $\mathrm{XV}(1)$

2. Depkes, 1989, Materia Medika Indonesia Jilid V, Jakarta : Direktorat Jenderal Pengawasan Obat dan Makanan.

3. Depkes, 2000, Parameter Standar Umum Ekstrak Tumbuhan Obat, Jakarta : Direktorat Jendral Pengawasan Obat dan Makanan.

4. Dalimartha., Setiawan., Hembing, Wijaya., 1997, Tanaman Berkhasiat Obat di Indonesia, jilid ke-3, Jakarta, 122-123.

5. Djoko, Hargono.,1986, Sediaan Galenik, Direktorat Jenderal Pengawasan Obat dan Makanan, Departemen Kesehatan Republik Indonesia.

6. Farnsworth, N. R., 1966, Biological and Phytochemical Screening of Plants, J. Pharm. Sci., 55(3), 243-268.

7. Fessenden, J.R. 1997, Dasar-Dasar Kimia Organik. Penerbit Binarupa Aksara, Jakarta, 546.

8. Gritter, R.J., J.M. Bobbit, and A.E.,1991. Schwarling, Pengantar Kromatografi, terjemahan K. Radmawinata dan I. Soediso, penerbit ITB, Bandung, 5-9, 160, $163,165,169$.

9. Harborne, J. B., 1987, Metode Fitokimia : Penuntun Cara Modern Menganalisis Tumbuhan, Bandung : Penerbit ITB.

10. Hariana, H.arief., Drs., 2000, Tumbuhan Obat dan Khasiatnya, Seri 3, Penebar Swadaya, Jakarta, 91.

11. Heyne, K. 1988, Tumbuhan Berguna Indonesia, Jilid 4, Yayasan Sarana Wana Jaya, Jakarta, 1456-1459, dan 2273.

12. Hovenkanp, P.H. Pirrosia Mirbel In: de Winter. W. P. \& Arnoroso. V.B. (eds.)., 2003, Plant Resources of South — East Asia No. 15 (2). Cryptogarns : Ferns aiid fern allies. Backhuys Publishers, Leiden, the Neitherlands, Pj):170-174.

13. Kusuma, Fauzi R., Zaky, B.Muhamad., 2005, Tumbuhan Liar Berkhasiat Obat, Agromedia Pustaka, Jakarta, 283.

14. Lestari, Widya. 2008, Beberapa Parameter Standar Dan Telaah Fitokimia Rhizoma Binahong (Anredera Cordifolia (Tenore steen)), Unjani, Bandung, 5-7. 
15. Markham. K.R., 1988, Cara Mengindentifikasi Flavonoid, terjemahan K. Radmawinata, Penerbit ITB, Bandung, 1-117.

16. Stahl, E., 1985, Analisis Obat Secara Kromatografi dan Mikroskopi, terjemahan K. Radmawinata dan I. Soediso, penerbit ITB, Bandung, 1985, 3-18.

17. Tjokronegoro, Roekmi., Dr., 2000, Teknik Pemisahan Kimia, Jurusan Kimia Fakultas MIPA Unpad, Bandung, 206-207, 230-231, 227.

18. Thomas, A., Pomammal, N.R., 2005, PG and Research Department of Botany, Kongunadu Arts and Science College,Vol XXV (2), 57-61.

19. Vijayvargia, P., Vijayvargia., R., 2014, Biological and Phytochemical Screening of Plants, J. Pharm. Sci., 28(1), 191-195. 